\title{
The twin purposes of Guided Inquiry: Guiding student inquiry and evidence- based practice
}

\author{
Lee FitzGerald \\ Head Teacher Librarian \\ Loreto Kirribilli \\ Sydney, Australia \\ lfitzgerald@loreto.nsw.edu.au
}

\begin{abstract}
Guided Inquiry is a means by which student enquiry can be facilitated in schools, while simultaneously being the vehicle for evidence-based practice. This paper illustrates this twin purpose in two contexts: An overview discussion of the 2008 NSW Association of Independent Schools' Project, led by Dr. Todd, and a 2010 Guided Inquiry at Loreto Kirribilli. Both projects are discussed as student practice and as a means of gathering data about student learning using the School Library Impact Measure (SLIM) Toolkit, while highlighting the use of wiki as an organising tool. Lastly, the paper affirms the impact that Guided Inquiry has had on some Sydney schools.
\end{abstract}

\section{Guided Inquiry}

Guided Inquiry is carefully planned, closely supervised targeted intervention of an instructional team of school librarians and teachers to guide students through curriculum based inquiry units that build deep knowledge and deep understanding of a curriculum topic, and gradually lead towards independent learning (CISSL, 2005).

It is grounded in a constructivist approach to learning, based on the Information Search Process developed by Professor Emerita Dr Carol Kuhlthau's extensive research over a twenty year period (Kuhltau, 2004).

Guided Inquiry means just what it says-teachers and teacher-librarians guide students through the process of doing an assignment. It is applicable both to long-term, open-ended assignments, such as the NSW Year 11 Historical Investigation, as well as to shorter, more contained assignments, which are obviously much more frequent. Essentially, Guided Inquiry seeks to scaffold students at the points in the information search process where they cannot proceed without difficulty. It asks both teachers and students to develop a greater awareness of process in research, and to develop an understanding of the thoughts, actions and feelings common to all researchers, whether primary, secondary or tertiary. It also respects the student's right to be autonomous in research, if they don't need any intervention.

\section{The research task/assignment}

At the base of Guided Inquiry is the assignment itself - ideally an open-ended assignment where students can choose their own topics, but in narrower assignments, the question needs at least to be constructivist in nature, forcing students to do more than transport information - to transform the information they have gathered into knowledge. In Guided Inquiry, open-ended assignments should not be unconnected with curriculum, rather they should seek to link to what Kuhltau (2007, p32-33) terms the First Space - students' local and cultural knowledge, including web 2.0 - with Second Space - school curriculum - the goals, standards, learning outcomes at the base of what is taught. The aim is to engage students in research that creates the Third Space - where students use out of school knowledge to make sense of the curriculum. Assignments which are 'go find out abouts...' do not connect first and second spaces, but result in transport of information with no deep understanding or interest. But curriculum-based assignments, aligned with students' interests and prior knowledge, can create the Third Space.

\section{The Information Search Process}

The Information Search Process lies at the heart of Guided Inquiry. 
Model of the Information Search Process

\begin{tabular}{|c|c|c|c|c|c|c|c|}
\hline & Initiation & Selection & Exploration & Formulation & Collection & Presentation & Assessment \\
\hline $\begin{array}{l}\text { Feelings } \\
\text { (Affective) }\end{array}$ & Uncertainty & Optimism & $\begin{array}{l}\text { Confusion } \\
\text { Frustration } \\
\text { Doubt }\end{array}$ & Clarity & $\begin{array}{l}\text { Sense of direction / } \\
\text { Confidence }\end{array}$ & $\begin{array}{l}\text { Satisfaction or } \\
\text { Disappointment }\end{array}$ & $\begin{array}{l}\text { Sense of } \\
\text { accomplish- } \\
\text { ment }\end{array}$ \\
\hline $\begin{array}{l}\text { Thoughts } \\
\text { (Cognitive) }\end{array}$ & vague & . & $\longrightarrow$ & focused & & & \multirow{2}{*}{$\begin{array}{l}\text { Increased } \\
\text { self- } \\
\text { awareness }\end{array}$} \\
\hline $\begin{array}{l}\text { Actions } \\
\text { (Physical) }\end{array}$ & seeking & $\begin{array}{l}\text { relevant } \\
\text { Exploring }\end{array}$ & information & seeking & $\begin{array}{c}\text { pertinent } \\
\text { Documenting }\end{array}$ & information & \\
\hline
\end{tabular}

(Kuhlthau, 2005)

Because it is supported by a great deal of evidence, from studies carried out by Carol Kuhlthau, (Kuhlthau, 2007, p. 21) Ross Todd and others (Kuhlthau et al, 2008), this model of information seeking and using behaviour is very telling. It is not a superimposed process, but describes the experience of thousands of researchers as they handle information.

Students at Loreto have responded well to the Research River analogy for the Information Search Process. This PowerPoint presentation aligns the stages of the Information Search Process to the passage of a river to the sea, from small and weak beginnings, to basking in the shallows of information, to steadily getting deeper into the flow of information, to falling down the waterfall then plunging headlong into The Dip predicted by Kuhltau at Exploration. After that, the river streams through various paths to the sea, leaving behind much of its water, and dividing into many possible paths. The analogy has proved helpful to students in describing and experiencing their information process, as the research described below at Loreto Kirribilli highlights.

The diagram of the Information Search Process above shows the affective domain - which all researchers experience. Most noticeable is The Dip which occurs at the exploration phase of an assignment, where the searcher goes into overload and experiences confusion, frustration and doubt. This is a critical zone of intervention by teachers and teacher-librarians for students.

Noticeable also is the length of time it takes in terms of stages to get to formulation of student understanding - their 'take' on the problem of the assignment. This applies whether the assignment is openended or not. Kuhlthau differentiates the types of searching students need to do at the different stages of the Information Search Process (Kuhlthau, 2007, p84). Students need to move from broad preliminary searching at the beginning of an assignment to develop a concept of the scope of their topic. Focus should be on reading broadly for understanding of the scope of the topic, then move to exploratory searching when they need to go deeper at the exploration stage, to comprehensive searching when they are formulating their own understanding or their own point of view on the topic. Lastly, before they write the product of their research, they need to do a summary search to make sure they haven't missed anything vital, or that information has changed.

Students participating in the recent Year 11 Historical Investigation were specifically instructed in this structured searching approach, but the research shows they still have more to learn about this.

\section{The 2008 NSW Association of Independent Schools' Project: Guiding student inquiry and collecting data about student learning}

As part of the 2008 NSW Association of Independent Schools/Catholic Education Commission Quality Teacher project, 12 independent schools in Sydney, Australia, carried out Guided Inquiry research in their schools, under the guidance of Dr. Todd. Wiki was the tool used for planning and carrying out the research. Available at http://giresearchers.pbwiki.com, the GI Researchers wiki was the communication tool for all

(C) 2010 IASL, SLAQ and therein by the authors. Diversity Challenge Resilience: School Libraries in Action Proceedings of the $12^{\text {th }}$ Biennial School Library Association of Queensland, the $39^{\text {th }}$ International Association of School Librarianship Annual Conference incorporating the $14^{\text {th }}$ International Forum on Research in School Librarianship, Brisbane QLD Australia, 27 September - 1 October 2010 . 
stages of this research, including ongoing leadership from Dr. Todd, planning, execution, sharing of scaffolding and the inquiry units themselves, and reporting of findings on this 12 school project.

This project is a demonstration of the twin purposes of Guided Inquiry as the means for a means by which open-ended student inquiry can be carried out and scaffolded, as well as providing a means by which evidence of student learning can be gathered during the inquiry, using reflection sheets.

With Dr. Todd's support, each school developed an open-ended research task with Guided Inquiry scaffolding, which we carried out in our schools. During the project, we sought feedback from our students at three critical points in their research, aimed at defining their growing knowledge of their topics, outlining their difficulties and defining what they find easy and difficult at the 3 stages of the Information Search process. This feedback provided us with material for direct interventions with our students, as well as data to be analysed using the School Library Impact Measure (SLIM) (Todd, et. al, 2005)

As Dr. Ross Todd will be disseminating findings and implications to a wider world audience in 2011, coverage of this project in this paper is restricted to an overview of aims and achievements.

The aims of the project were to engage participating teams of teachers and teacher-librarians in developing and carrying out Guided Inquiry units, based on the Information Search Process; to track changes in the language students used at different stages of their enquiry to describe their understanding of their topic; to find out what students find easy and difficult in research; and to learn to use the SLIM Toolkit for analysing data.

Participating schools were from the NSW Association of Independent schools, and included:

- Abbotsleigh

- Broughton Anglican College

- Loreto Kirribilli

- Newington College

- Northholm Grammar

- Queenwood
- Roseville College

- Santa Sabina (junior and senior)

- St. Luke's Grammar School

- St. Paul's Grammar School

- St. Vincent's College

- Wenona

Most projects were in Years 7-10, with 8 in History, 1 each in English and PDHPE, 2 in Geography and 1 in Science. Two primary schools were involved, with projects in Year 5 Geography and Year 4 Science. All projects had significant teaching input from teachers and teacher-librarians. In total, 34 teachers, 18 teacher-librarians and 935 students took part.

\section{Each inquiry unit involved}

- $\quad$ use of the Information Search Process as the instructional design framework.

- planning of instructional interventions to initiate the project, to help students select topics, build background knowledge, develop specific focus questions, analyse, synthesise, deal with conflicting knowledge, develop arguments, and develop personal positions and perspectives.

- $\quad$ an area of inquiry which allowed students freedom to develop their own focus questions.

- developing and using existing background knowledge.

- high quality resources for students and instruction in their use.

The project focused on the

- $\quad$ presence of teachers and teacher-librarians at each stage of the process to guide and intervene, both in planned ways, and in unplanned ways which arose out of information provided by students in the SLIM Reflection Sheets.

- $\quad$ process more than product, and most did not tell students what the product was to be until they had passed the Collection phase of the Information Search Process.

- gathering of data from students at three points of the Information Search Process - at Initiation, at Collection, and at Assessment.

\section{Methodology}

Data were gathered from students at Initiation, Collection and Assessment using the SLIM Toolkit

(Todd, et.al 2005). These questions were asked at each stage:

(C) 2010 IASL, SLAQ and therein by the authors. Diversity Challenge Resilience: School Libraries in Action Proceedings of the $12^{\text {th }}$ Biennial School Library Association of Queensland, the $39^{\text {th }}$ International Association of School Librarianship Annual Conference incorporating the $14^{\text {th }}$ International Forum on Research in School Librarianship, Brisbane QLD Australia, 27 September - 1 October 2010. 
1. Write the title that best describes your research project at this time.

2. Take some time to think about your research topic. Now write down what you know about this topic.

3. What interests you about this topic?

4. How much do you know about this topic? Check $(\checkmark)$ one box that best matches how much you know. Nothing, Not much, Some, Quite a bit and A great deal

5. Write down what you think is EASY about researching your topic.

6. Write down what you think is DIFFICULT about researching your topic.

7. Write down how you are FEELING now about your project. Check $(\checkmark)$ only the boxes that apply to you. Confident, Disappointed, Relieved, Frustrated, Confused, Optimistic, Uncertain, Satisfied, Anxious or Other.

The third reflection sheet also included students' reflections on what they had learnt. These are the standard questions of the SLIM Toolkit.

\section{Results}

Each school showed substantial growth to deep knowledge (as evidenced by number of explanations). This finding will be elaborated on by Dr. Todd in a coming article for School Libraries Worldwide.

Difficulties students faced were identical in all the schools:

- Developing focus questions - that formulation of a question takes a long time.

- Finding the "right" information targeted to focus - looking for the 'right answer'.

- Taking notes - link found with poor notetaking and plagiarism.

- Synthesising information: putting information together, developing arguments, conclusions.

- Acknowledging sources.

- Interest dip at formulation stage, in line with the stages of the Information Search Process.

It is interesting that all schools reported difficulties in locating the right information for the stage of the research process, and is strong support for the different kinds of searching advocated by Kuhltau (2007, p84), preliminary, exploratory, comprehensive and summary searching. This aspect is reinforced in the small Loreto study following.

\section{Conclusions}

Anecdotal evidence in reflections of teachers and students added to the qualitative findings provide support for Guided Inquiry in its first purpose: a structured process to support and guide inquiry units. The feedback element was highly regarded by teachers as formative assessment, and by students as a source of personalised and relevant help. Students displayed growing metacognition about information processes and expressed continuing interest, even in the Dip at Exploration, because they were able to own their research and inquiry questions.

Teacher-librarians involved developed understanding how the SLIM reflection sheets can be used both for guiding interventions with students on an individual and group basis, and as an individual diagnostic tool for formative assessment.

In essence for teacher-librarians, Guided Inquiry as demonstrated through this research project provides a way of making information literacy a mainstream element of the major assessment tasks students encounter in their school life. Wiki is a valuable tool for the interaction and feedback that Guided Inquiry demands. It also was a clear demonstration of the twin purposes of Guided Inquiry Using reflections from students in two ways - providing feedback to them, and using the reflection sheets for data to be analysed for evidence-based practice.

\section{The 2010 Loreto Kirribilli Year 11 Modern Historical Investigation: Guiding student inquiry and collecting data about student learning}

The task under consideration to show how Guided Inquiry methods facilitate students enquiry is the Year 11 Modern Historical Investigation, mandatory in NSW schools. It was carried out in May/June

(C) 2010 IASL, SLAQ and therein by the authors. Diversity Challenge Resilience: School Libraries in Action Proceedings of the $12^{\text {th }}$ Biennial School Library Association of Queensland, the $39^{\text {th }}$ International Association of School Librarianship Annual Conference incorporating the $14^{\text {th }}$ International Forum on Research in School Librarianship, Brisbane QLD Australia, 27 September - 1 October 2010. 
this year, using a wiki to hold all the steps of the investigation. This is available at http://11modernbleby.pbworks.com

The Modern Historical Investigation allows students to choose an area of interest which contains historical debate, within the constraints of the syllabus, to research widely and deeply to develop their own inquiry question. The final product of this guided effort is a scholarly essay, in which students answer their own question, using scholarly conventions such as footnotes. Both process and product are marked in this assignment, teachers marking the essays, and teacher-librarian marking the process. Cross-marking of the essays allowed the teacher-librarian to see the impact of process on product.

Teachers and teacher-librarians have collaborated over the last three years to work out the best way of presenting this Guided Inquiry. The front page of the wiki contains a brief description of the project, and essential dates, while on the side bar are the assignments elements:

- the task itself,

- reflection sheets,

- peer evaluation,

- self reflections,

- annotated notetaking grids, and

- resources, which include The Research River, developing questions, essay planning, writing footnotes.

In this year's enquiry, each student had her own page, where she wrote a daily learning journal, uploaded the reflection sheets as required, with developing notetaking grids. This is where teachers, teacher-librarians and peers provide feedback, using the comment function of wiki.

\section{Reflection sheets provided information for interventions required (individual and group), as well as data to be analysed using the SLIM Toolkit. This is the essence of the twin purposes of Guided Inquiry scaffolding.}

\section{Evidence-based practice}

Goals of case study:

We observed the research process used by students involved in open-ended enquiry supported by Guided Inquiry scaffolding, in particular:

- to measure changes in knowledge as students pass through the stages of the Information Search Process, in terms of the type of statements students make about their topic, i.e. by observing how often they make factual statements, explanations or conclusions.

- to find out what students find difficult when researching and to compare this with expressed learnings at the end of the project.

- to gather reflections on the Information Search Process.

It is important to add at this stage that the evidence-based practice was a simple second use of the scaffolding of the assignment. This is a very small scale study, of what is a very high quality Guided Inquiry in terms of the output of students, which was carried out in 2 classes, using wiki and in identical fashion. There was no time, however, to analyse the responses of the second class.

The following analysis was a by product of the assignment itself, and data for the analysis was all part of the assignment itself, and so it was really quite easy to do this analysis.

Our research questions were:

1. What do you know about your topic?

2. Have you any particular difficulties relating to your topic?

3. What have you learnt from this Guided Inquiry?

4. Describe your feelings are you progressed through the stages of the Information Search process - Initiation, Selection, Formulation/Exploration, Collection and Presentation.

(C) 2010 IASL, SLAQ and therein by the authors. Diversity Challenge Resilience: School Libraries in Action Proceedings of the $12^{\text {th }}$ Biennial School Library Association of Queensland, the $39^{\text {th }}$ International Association of School Librarianship Annual Conference incorporating the $14^{\text {th }}$ International Forum on Research in School Librarianship, Brisbane QLD Australia, 27 September - 1 October 2010. 


\section{What do you know about your topic?}

We wanted students to synthesise their growing understandings of their topic in a way that was not an add on to the assignment, as experience from the 2008 Guided Inquiry showed us that students resent taking the time to write down 3 times their understanding of the topic. This question was administered in reflection sheet 1 at Initiation and 2 at Formulation. At Collection, students wrote an essay plan, which was useful to them to organize the information, but not useful to us in data collection. Lastly, for question1, we analysed the essays themselves, which were a sure guide to student growth towards deep knowledge, executed with real purpose and a reliable guide to what they ended up knowing about their topics.

\section{Have you any particular difficulties relating to your topic?}

This question was administered at Reflection sheet 1, 2 and 3 (just before Presentation), as we wanted information from students as to what interventions they needed on a personal and class basis. This is essential to Guided Inquiry in its first purpose, guiding the inquiry of students by using feedback from them to tailor individual and group interventions. This was the essence of the work the teachers and teacher librarían did on this Project, providing feedback in person, and on the wiki, using the comment function.

\section{What have you learnt from this Guided Inquiry?}

This question was administered in Reflection sheet 4, at the end of the task. We used the same information skills headings as in What did you find difficult? so that we could make some conclusions about what they learnt relating to what they found difficult.

\section{Describe your feelings are you progressed through the stages of the Information Search process- Initiation, Selection, Formulation/Exploration, Collection and Presentation.}

Lastly as Question 4, we gathered their reflections on the Information Search Process, which are analysed below, showing casebook links particularly with the Dip in the Formulation stage, expressed by many students. At the introduction of this unit, students were taken through the Information Search Process, using the Research River powerpoint as an analogy, and so many students couched their reflections using this analogy.

To reiterate, our Year 11 Guided Inquiry is a good example of the twin uses of Guided Inquiry scaffolding, particularly reflection sheets. The reflection sheets were central to student inquiry proceeding, providing a feedback mechanism between teachers, teacher-librarians and students; but they also provided analyzable data about student growth to deep knowledge, to what they find difficult, to what they learnt, and to the intrinsic nature of the Information Search process to Guided Inquiry.

\section{Participants:}

15 Year 11 students at Loreto Kirribilli, Sydney, Australia. Loreto Kirribilli is an Independent Catholic day school with an enrolment of approximately 1040 girls from Kindergarten to Year 12.

\section{Data Collection:}

We gathered data at three stages of the Information Search process - Initiation, Formulation and Presentation.

\section{Findings:}

Question 1: What do you know about your topic?

This was the question which analysed changes in student knowledge by coding student responses according to whether they were facts, explanations or conclusions. We collected data at Initiation, Formulation and Presentation (essay itself) the $12^{\text {th }}$ Biennial School Library Association of Queensland, the $39^{\text {th }}$ International Association of School Librarianship Annual Conference incorporating the $14^{\text {th }}$ International Forum on Research in School Librarianship, Brisbane QLD Australia, 27 September - 1 October 2010. 


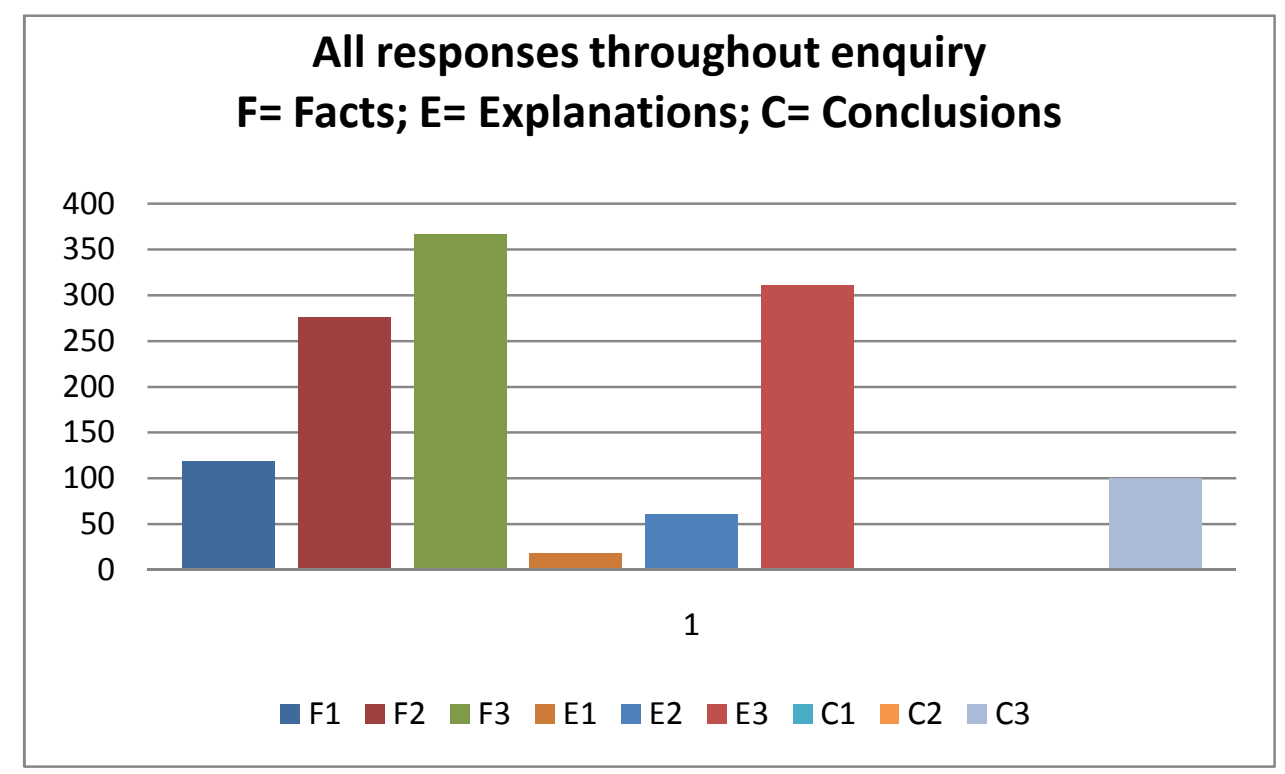

Analysis:

For all students, there were high level of facts at all stages of the project, an increasing number of explanations, reaching a peak in the essay; no conclusions in early stages, very small number mid stage, and an impressive 100 conclusions drawn from all essays.

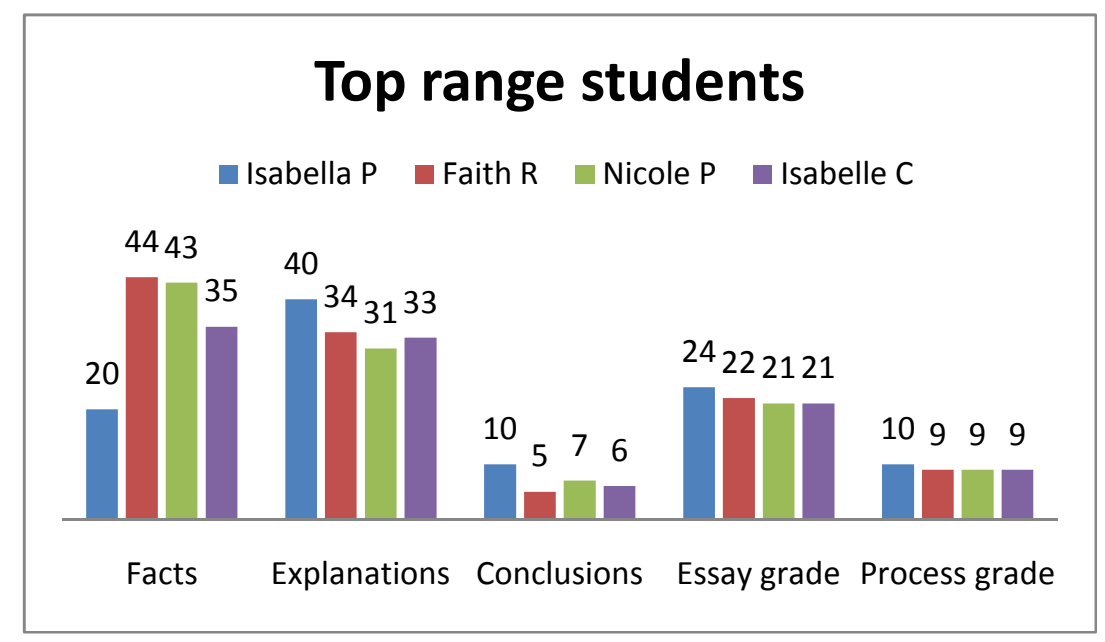

Analysis:

All students in the top range had a large number of explanations, as well as a substantial number of conclusions, showing high levels of synthesis. Students who achieved most highly also show a clear link between high achievement in process and high achievement in product.

\section{Isabella - Blue}

The highest achieving student made the biggest number of conclusions, starting making explanations early, made the fewest number of facts at outset. Her topic was the reasons for the waxing and waning of support for the Klu Klux Klan over time, not a simple topic by any means, and she set about very early looking for patterns in her information gathering. the $12^{\text {th }}$ Biennial School Library Association of Queensland, the $39^{\text {th }}$ International Association of School Librarianship Annual Conference incorporating the $14^{\text {th }}$ International Forum on Research in School Librarianship, Brisbane QLD Australia, 27 September - 1 October 2010. 
Faith: Brown

Faith began with highest number of facts, second largest number of explanations, but her conclusions were the smallest. This finding and her high achievement in essay and process may be related to her topic - The Fall of Berlin Wall - as a discrete and not too complicated area.

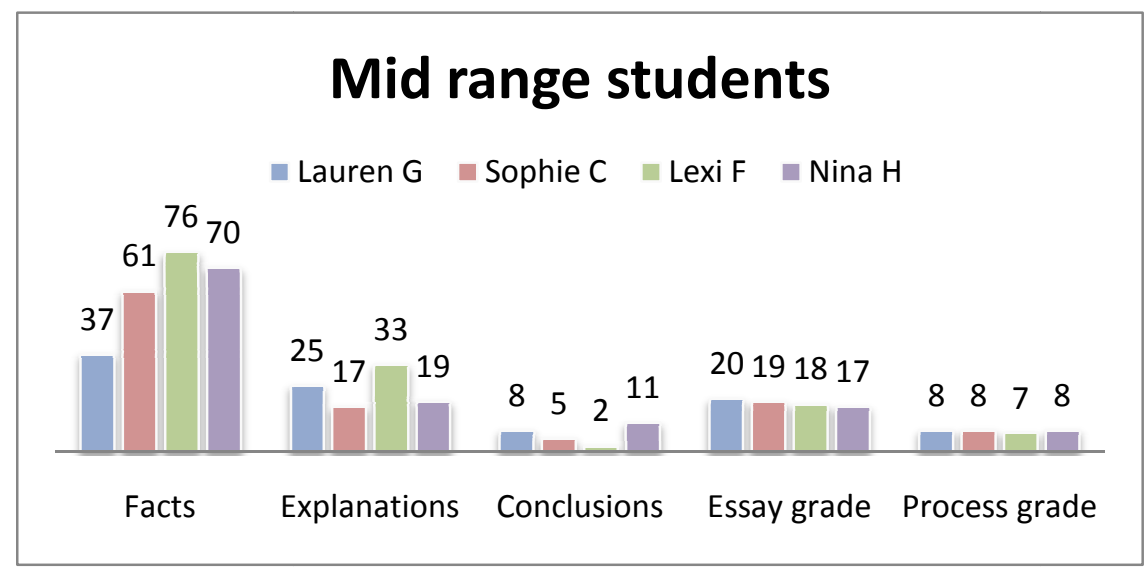

Lauren G, (blue) Sophie C (pink) and Nina H (purple) - show good numbers of facts/explanations/conclusions. Lexi $F$ (green) had a very large number of facts, a reasonable number of explanations, hardly any conclusions. She gathered all the information at the first stage, in depth, then did not add to it, or synthesise it. This is why she says later that the Collection stage, at which she should THEN have been gathering indepth information, is unnecessary. Lexi needed to gather broad overview information first, to then add to it with broader information, using Google and books, then to go very much deeper at the Collection stage, to enrich and understand her topic.

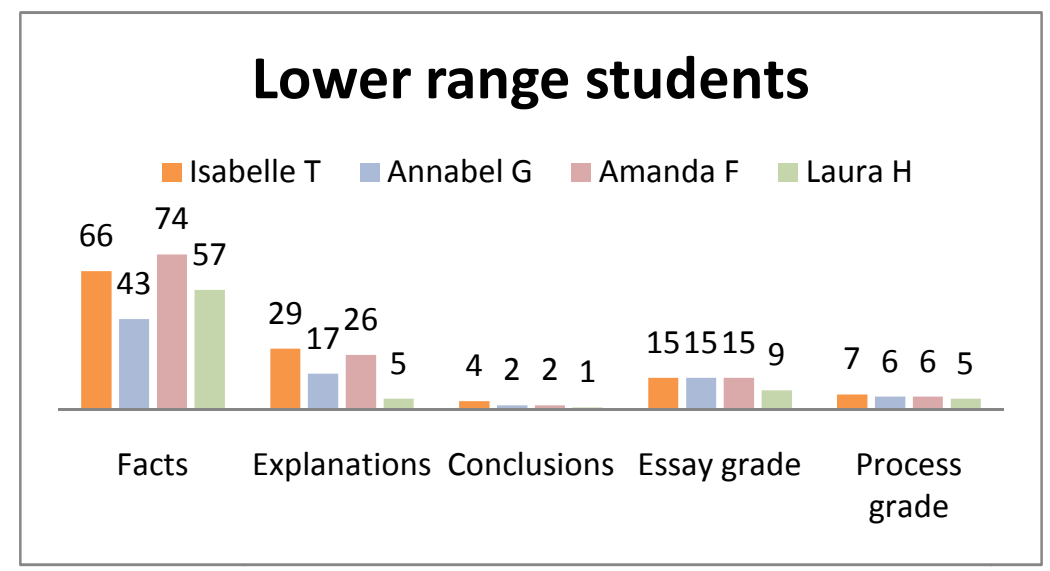

The above four show a diminishing number of explanations and conclusions.

Implication for Loreto

More explicit teaching may be needed on the kinds of searching appropriate to each stage, and highlighted above in Kulhtau's preliminary, exploratory, comprehensive and summary searching concepts (Kuhltau, 2007, p84). Students need to be taught to begin with overview information so they can gain a basic understanding of the scope of their topic, before they steadily go deeper as the enquiry proceeds. We did stress this in the process of this Guided Inquiry, but there is evidence to show that it needs to be reinforced, particularly finding ways of emphasising ongoing synthesis of

(C) 2010 IASL, SLAQ and therein by the authors. Diversity Challenge Resilience: School Libraries in Action Proceedings of the $12^{\text {th }}$ Biennial School Library Association of Queensland, the $39^{\text {th }}$ International Association of School Librarianship Annual Conference incorporating the $14^{\text {th }}$ International Forum on Research in School Librarianship, Brisbane QLD Australia, 27 September - 1 October 2010. 
information to work towards establishing patters, (explanations, conclusions) earlier in the journey to understanding a topic.

Question 2 and Question 3: Have you any particular difficulties relating to your topic?and What have you learnt from this Guided Inquiry? These questions were combined to show difficulties expressed, and self expressed learnings at end of project.

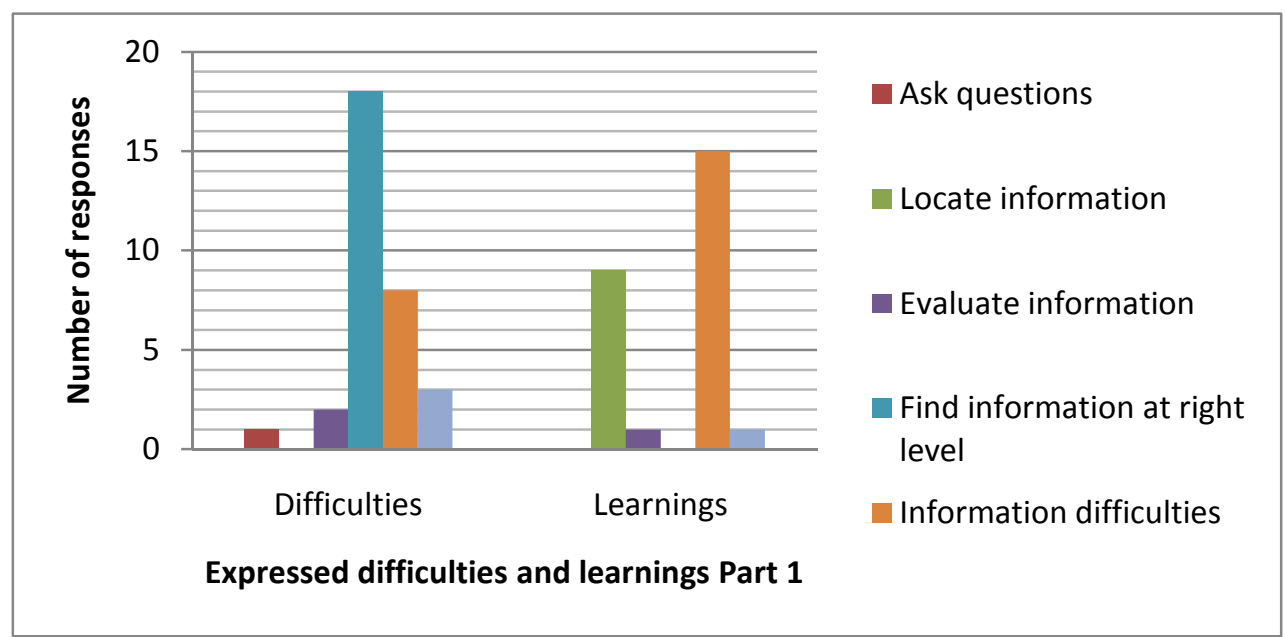

Analysis:

Problems with evaluating information (purple) have been addressed in the project, according to students. Students did not think they had any difficulties locating information (green) but it is finding it at the right level that is problematic (blue). This reinforces the findings in the 2008 AIS Guided Inquiry Project. Students search too deeply at first, when what they need then is overview information. We taught them how to search for an overview at first, then move to deeper information, and when their question is developed to use online databases. Anecdotally students expressed that they've learnt this, but this is not reinforced in this graph. It is clear that it needs further explicit teaching.

Information difficulties (orange) referred to overload, underload, and unevenness of quality of information. Students feel strongly that they've learnt this from this Project, and we experienced great success with Questia and History Study Centre, our online History databases. Teachers and teacherlibrarians feel that students have taken in the advantages of using quality information. 


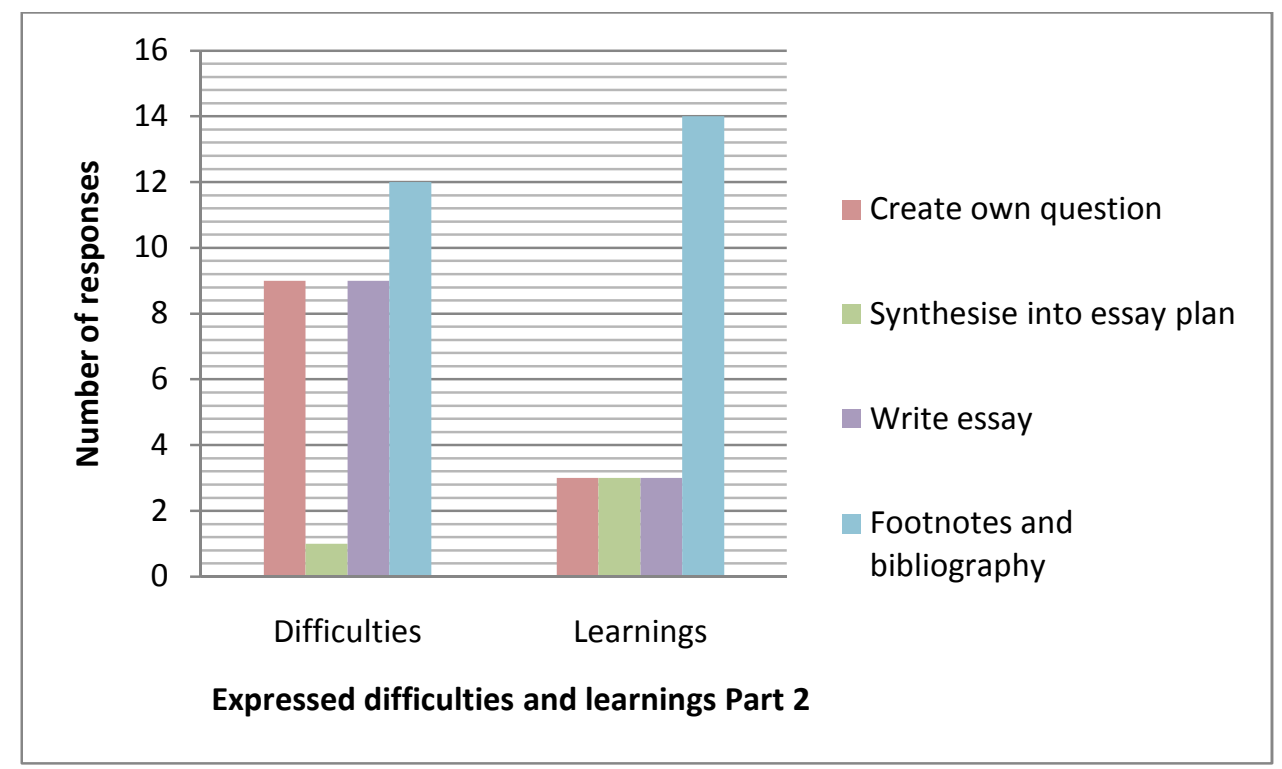

Analysis:

Difficulties with creating own question (pink) shows that some students felt that they've learnt quite a lot about this, but a big percentage expressed that they found this hard.

Creating essay plan (green) - Students had few difficulties with this, and found it relatively easy.

Write essay (purple): Students found ound this difficult, and only a few felt they'd learnt it properly.

Do footnotes and bibliography (blue): This area looks like a resounding success, with more people said they'd learnt it than those who had difficulties with it!

\section{Implications for Loreto:}

It is clear that students find it difficult to develop their own questions, and that they experience a Dip in confidence similar to that experienced earlier on at Formulation when they are in information overload, from this small numerical analysis and from the anecdotal evidence following.

Implications of topic choice:

Anecdotally again, it was clear to teachers and teacher-librarían that the topic chosen impacted on student process. Those who chose topics which are very complex and highly written about had difficulties carving a path through the information, while others who wrote about areas that have virtually nothing written about them, experienced difficulty as well. This was evident in one of our student's decisión to compare Kokoda with Gallipolli, which no one has ever done before!

Question 4: Describe your feelings are you progressed through the stages of the Information Search process - Initiation, Selection, Formulation/Exploration, Collection and Presentation.

\begin{tabular}{|l|l|l|l|l|l|}
\hline & Initiation & \multicolumn{1}{|c|}{ Selection } & $\begin{array}{l}\text { Formulation/ } \\
\text { Exploration }\end{array}$ & Collection & Presentation \\
\hline Louisa B & $\begin{array}{l}\text { Confusion, } \\
\text { excitement }\end{array}$ & A sort of frenzy & Deep in the Dip & Confident & Another Dip \\
\hline Isabelle C & $\begin{array}{l}\text { Unsure, } \\
\text { optmistic }\end{array}$ & Daunted & Very unsure & Confident & Difficult \\
\hline
\end{tabular}

(C) 2010 IASL, SLAQ and therein by the authors. Diversity Challenge Resilience: School Libraries in Action Proceedings of the $12^{\text {th }}$ Biennial School Library Association of Queensland, the $39^{\text {th }}$ International Association of School Librarianship Annual Conference incorporating the $14^{\text {th }}$ International Forum on Research in School Librarianship, Brisbane QLD Australia, 27 September - 1 October 2010. 


\begin{tabular}{|c|c|c|c|c|c|}
\hline Sophie C & $\begin{array}{l}\text { Worried, } \\
\text { daunted }\end{array}$ & $\begin{array}{l}\text { Changed topic, } \\
\text { but happy }\end{array}$ & Lots of trouble & $\begin{array}{l}\text { Relatively } \\
\text { easy }\end{array}$ & Big Dip \\
\hline Amanda $\mathrm{F}$ & Enthusiastic & Indecisive & Anxious & $\begin{array}{l}\text { On the right } \\
\text { track }\end{array}$ & $\begin{array}{l}\text { Very stuck } \\
\text { writing essay }\end{array}$ \\
\hline Lexi F & $\begin{array}{l}\text { Freedom to } \\
\text { research } \\
\text { anything }\end{array}$ & $\begin{array}{l}\text { Not very } \\
\text { confused }\end{array}$ & $\begin{array}{l}\text { Unsure, quite } \\
\text { stressed }\end{array}$ & $\begin{array}{l}\text { Seen as not } \\
\text { necessary* }\end{array}$ & N/A \\
\hline Camille G & $\begin{array}{l}\text { Liberated } \\
\text { and excited }\end{array}$ & $\begin{array}{l}\text { Uneasy, topic v. } \\
\text { big }\end{array}$ & $\begin{array}{l}\text { Maximum } \\
\text { anxiety }\end{array}$ & $\begin{array}{l}\text { In tune with } \\
\text { the River }\end{array}$ & $\begin{array}{l}\text { Overwhelming, } \\
\text { confusing, } \\
\text { overload of } \\
\text { information }\end{array}$ \\
\hline Lauren G & $\begin{array}{l}\text { Enthusiastic } \\
\text { and excited }\end{array}$ & $\begin{array}{l}\text { Tiresome, but } \\
\text { content }\end{array}$ & $\begin{array}{l}\text { Still cruising } \\
\text { down river }\end{array}$ & $\begin{array}{l}\text { Hit a boulder } \\
\text { in the middle } \\
\text { of the river, } \\
\text { question } \\
\text { change }\end{array}$ & $\begin{array}{l}\text { Very tiring rock } \\
\text { wall to climb in } \\
\text { the research river }\end{array}$ \\
\hline Annabel G & Optimistic & $\begin{array}{l}\text { Good state of } \\
\text { mind }\end{array}$ & $\begin{array}{l}\text { Anxiety over area } \\
\text { of debate }\end{array}$ & $\begin{array}{l}\text { Changed } \\
\text { course } \\
\text { slightly }\end{array}$ & $\begin{array}{l}\text { Quite excited to } \\
\text { get started on } \\
\text { essay }\end{array}$ \\
\hline Laura $\mathrm{H}$ & Excited & Less excited & Less interested & $\begin{array}{l}\text { Changed } \\
\text { course } \\
\text { slightly }\end{array}$ & $\begin{array}{l}\text { Difficult and } \\
\text { disappointing }\end{array}$ \\
\hline Nina $\mathrm{H}$ & Unsure & $\begin{array}{l}\text { Happy with } \\
\text { choice }\end{array}$ & $\begin{array}{l}\text { Choosing a } \\
\text { question difficult }\end{array}$ & $\begin{array}{l}\text { Easy and } \\
\text { interesting }\end{array}$ & $\begin{array}{l}\text { The most difficult } \\
\text { stage, word limit } \\
\text { and answering } \\
\text { question }\end{array}$ \\
\hline Sophie M & $\begin{array}{l}\text { Very } \\
\text { interested }\end{array}$ & $\begin{array}{l}\text { Difficult, too } \\
\text { much info }\end{array}$ & $\begin{array}{l}\text { Choosing a } \\
\text { question difficult }\end{array}$ & $\begin{array}{l}\text { Difficult to } \\
\text { organise } \\
\text { because } \\
\text { question } \\
\text { uncertain }\end{array}$ & $\begin{array}{l}\text { Very happy with } \\
\text { this }\end{array}$ \\
\hline Isabella P & $\begin{array}{l}\text { Excited, } \\
\text { unsure }\end{array}$ & $\begin{array}{l}\text { Definite about } \\
\text { topic }\end{array}$ & $\begin{array}{l}\text { Change in } \\
\text { direction difficult }\end{array}$ & Not difficult & $\begin{array}{l}\text { Extensive work, } \\
\text { but happy }\end{array}$ \\
\hline Nicole P & $\begin{array}{l}\text { A little } \\
\text { anxious }\end{array}$ & N/A & $\begin{array}{l}\text { Very unsure, } \\
\text { overloaded }\end{array}$ & N/A & N/A \\
\hline Faith $\mathrm{R}$ & $\begin{array}{l}\text { Very hard to } \\
\text { choose topic }\end{array}$ & $\begin{array}{l}\text { Difficult but } \\
\text { interesting }\end{array}$ & $\begin{array}{l}\text { Hard being } \\
\text { organised }\end{array}$ & Getting there & Pride of my work \\
\hline Isabelle T & $\begin{array}{l}\text { Very hard to } \\
\text { choose topic }\end{array}$ & $\begin{array}{l}\text { A feeling of } \\
\text { worry }\end{array}$ & $\begin{array}{l}\text { Making question } \\
\text { very hard }\end{array}$ & $\begin{array}{l}\text { Easier than I } \\
\text { expected }\end{array}$ & $\begin{array}{l}\text { Overwhelming } \\
\text { and a bit of a } \\
\text { worry }\end{array}$ \\
\hline
\end{tabular}

(C) 2010 IASL, SLAQ and therein by the authors. Diversity Challenge Resilience: School Libraries in Action Proceedings of the $12^{\text {th }}$ Biennial School Library Association of Queensland, the $39^{\text {th }}$ International Association of School Librarianship Annual Conference incorporating the $14^{\text {th }}$ International Forum on Research in School Librarianship, Brisbane QLD Australia, 27 September - 1 October 2010. 
Analysis:

There is strong support for the Dip in confidence at Formulation, with everybody except one experiencing it. There is a case from our reflections for another Dip in the Research process creating the essay. It also anecdotally reinforces a major finding - that it is the type of searching a student does at the different stages of the research process that impacts very heavily on their progress without too much pain throught the Information Search Process. Student reflections above are a reason by themselves for doing a Guided Inquiry - the level of metacognition brought to their information process is an end in itself.

And anecdotally:

"I think using the research river process (although slightly corny) is very useful as it allows us to properly plan our research processes and make sure we don't leave our work up until the last minute." Lauren $\mathrm{G}$

"I think this is one of the first assignments where all I had to do the night before it was due was read through and edit any weaker parts of my essay and ensure that it all made sense and was written well (as well as the footnoting and bibliography etc) For this I am very proud of myself." Lauren G

From top student, Isabella P: “Once I finished this process, I felt an immense relief and accomplishment, as I had put a great effort into the research and writing of this essay. I particularly liked the notetaking tables that we were suggested to use as they assisted me in taking more concise notes from my sources as well as the bibliographic details."

There was a second class doing this Guided Inquiry, Ms. Gabi Jory's class. Here are some of their responses. In general, they:

- liked choosing own question.

- thought that notetaking grids helped with organisation.

- felt that next time they should only have one notetaking grid which is added to as the assignment progresses.

- thought reflection sheets kept them on track.

- were not strong on learning journal and peer evaluation. (In general, this year, the peer evaluation section did not work as well as last year - it was probably done too close to the writing of the essay and girls felt their time could have been spent better.)

Student comments:

Amelia B:

"I have.. developed an analytical voice needed for my historical arguments I am ..glad that our processes are being marked as I feel it motivated me to research and reflect more thoroughly than I have before. I found the notetaking grid forced me into summarising the information in a visual way so I knew I was not plagiaring. When it came to incorporating such arguments into my own essay, it made it easier to distinguish that I was writing my own points. History Study Centre and Questia I will use in other assignments. I was really proud of my work because it was the most effort I have ever put into the research stage of a project and I felt that it was justified in the end."

Maddie G:

"I have become aware of more accurate and relevant information sites such as Questia and other school subscriptions."

Michaela M:

"The notetaking grid made the actual writing of the essay a lot less stressful because I knew I had all the information I needed."

(C) 2010 IASL, SLAQ and therein by the authors. Diversity Challenge Resilience: School Libraries in Action Proceedings of the $12^{\text {th }}$ Biennial School Library Association of Queensland, the $39^{\text {th }}$ International Association of School Librarianship Annual Conference incorporating the $14^{\text {th }}$ International Forum on Research in School Librarianship, Brisbane QLD Australia, 27 September - 1 October 2010. 
Georgia V:

"I have also learnt how to properly use citations in my essay and establish a accurate reference list. This will be helpful to use in other assignments to avoid plagiarism."

Annabelle W:

"The notetaking grids were a very useful and organised way to record and summarise information. It also got my bibliographic process out of the way, so when it came time to create my bibliography, it was half done for me already. These grids really kept my information organised and succinct, and gave me a clear view of where I was going and what else I needed to complete."

\section{Major findings:}

Research aim 1: To measure changes in knowledge as students pass through the stages of the Information Search Process, in terms of the type of statements students make about their topic i.e. whether they make factual statements, explanations or conclusions.

Conclusions:

Todd (2006) found a pattern in students' knowledge construction which he described as "an integrative approach" where students "did not see the task as one of just gathering facts at each stage, rather they manipulated these facts in a number of ways: building explanations, synthesizing facts into more abstract groupings, and consequently reducing the number of statements in their representations, organizing facts in more coherent ways, reflecting of facts to build positional, predictive conclusion statements". Most of the students in this small scale research project fit into this pattern, and we should be proud of the move towards deep knowledge exhibited in this project.

\section{Research aim 2: To find out what students find difficult when researching and whether they felt they had learnt how to overcome these difficulties Conclusions:}

There was evidence in our 2008 PDHPE Guided Inquiry to suggest that students only say that a research skill is easy, prior to actually doing it. When they said that locating is easy, this turned out not to be the case when they were actually doing it and looking at complex, biased and sometimes unreliable information. This is reinforced with this study, showing that there were no students who thought they had difficulty locating information at the outset, but it turned out as they progressed that locating the right information for the level of research they were at was a crucial obstacle.

We can conclude that students need more work on how to search in an appropriate way for the stage they are at, using the concepts of preliminary, exploratory, comprehensive and summary searching that Kuhlthau (2007, p84) recommends - essentially moving from encyclopedias at Initiation; to books and Google at Formulation, and then to the quality information available in online databases at Collection, finishing with a summary search just prior to Presentation.

\section{Research aim 3: To gather reflections of our students on the Information Search Process}

Our students' comments are text book reflections of the Information Search Process. It is of great value to students to know that the process they undertake every time they have a research task sees them undergoing the stages of the Information Search Process, and that it is normal, for example, to feel overloaded and confused at Formulation - where students are either creating their own question in an open-ended Guided Inquiry, or in a more closed enquiry, formulation their own 'take' on the information. It is perhaps self-evident that this small group of students demonstrated a second Dip in the information process - when they have to synthesise all, and create the final product. But most of them felt much more ready to write their essay than they normally do, because of the preparation that they did beforehand - notetaking grids, ongoing support from teacher and teacher-librarian, lessons on referencing, keeping bibliographic details from the beginning. 


\section{Concluding statement: Implications for practice at Loreto Kirribilli}

Naturally it would not be practical to include all the elements of a open ended Guided Inquiry every time students do assignments. Combined with wiki, however, it is the perfect way to do the quite regular open-ended research tasks that come up in, e.g. Senior Geography Project, Year 11 Modern and Ancient Historical Investigations. In more regular assignments, where the question is given, and the scope of the research is the same for each students, it is clear that there are benefits still in teaching students how to search at the various steps in their information process. It also appears that students need more experience in developing their own questions, in dealing with information overload, underload and uneven quality; in working on an ongoing basis from the beginning of a task to force synthesis of information to enable students to make explanations and conclusions.

As far as this teacher-librarian is concerned, accompanying students right through this learning journey, showed me that my resourcing changed in each individual case, mirroring each student's journey to defining question and locating the area of debate. I found the work intense, as I helped them with online databases, using our own and the State Libraries' excellent range, trying to help students locate the perfect piece that might have been missing, e.g. the Siege of Malta question which was completely missing the Maltese reaction side, and it took the student and me a very long time to locate the missing links.

It was a very big workload, but to have students begin to understand the role of the library in helping them research was rewarding.

\section{Impact of Guided Inquiry on Sydney schools}

A summary follows of developments in some of the participating schools since 2008.

\section{Broughton Anglican College}

Alinda Sheerman, head of Library, reported on a further action research project in 2009 - a cross curricular Year 7 Humanities Project, which she presented to her school's staff, which led to much interest in Guided Inquiry. She has been involved this year in Year 7 inquiry projects, Year 8 Science, and Year 5/6 for Murder under the Microscope, using Guided Inquiry principles.

This term she is doing Guided Inquiry Action Research with a Year 10 Commerce class. They are doing the optional unit of work called "Issues in Australia". She reports on the convenience of wiki to house the units of work, and that teachers have followed through with setting up and running wikis themselves. Alinda reports that she is constantly overwhelmed with the workload but admits to 'enjoying' it!

\section{Loreto Kirribilli}

Guided Inquiry elements have been incorporated into many assignments, across the curriculum - e.g. structured notetaking, scaffolds to assist with synthesis of information; bibliographic and citation scaffolds, explicit teaching of different types of searching at different stages of the process.

Full, open-ended Guided Inquiries have been running over the last three years in History, with overwhelmingly positive response from students.

Teachers have recognised in most subjects that students need support through the various stages of research, that elements of choice need to be applied to as many tasks as posible, that the research question needs to be higher order, that top quality resources are needed, that students need help with notetaking, synthesising, referencing, and creating their final product.

Students are now much more aware of process in their assignments, to a greater or lesser extent appreciating the scaffolding of their tasks throughout the years. They value expressing their the $12^{\text {th }}$ Biennial School Library Association of Queensland, the $39^{\text {th }}$ International Association of School Librarianship Annual Conference incorporating the $14^{\text {th }}$ International Forum on Research in School Librarianship, Brisbane QLD Australia, 27 September - 1 October 2010. 
difficulties and their growing knowledge of their topics, and the feedback available to them from teachers and teacher librarians.

Teacher-librarians have always known the value of collaboration in creating inquiry units, and in working alongside teachers to ensure students have a successful research experience. We are delighted that Guided Inquiry has given us the means to do this is an accepted, and relatively simple way.

\section{Roseville College by Jeanette Harkness}

We have come a long way with our Guided Inquiry since 2008. This year we are working with Year 9 History for the 3rd year with 3 classes. The History department say they already have anecdotal evidence that the Year 10s and 11s are far better prepared for their independent research project because of the Guided Inquiry project they did in Year 9.

We have begun working with Year 9 Commerce on a Guided Inquiry project running for 15 weeks with 3 classes. This time period will give us the opportunity to run classes on Blooms questioning at the Exploration stage of the unit. The overall topic area is Crime.

Both the above are assessment tasks where the process is half (Commerce) or one third (History) of the total mark.

For both, we will run the full SLIM assessment and each girls' progress in terms of interest, number of facts and number of explanations and conclusions will be graphed and used as normative assessment.

As a result of Guided Inquiry success here, the library now has 1 period per cycle for all of Year 7 - 4 classes. All lessons work towards a Guided Inquiry unit for semester 2 which is produced on a class wiki. Results will be graphed for assessment.

Finally, I have been asked to join a new committee called the Academic Care Committee. The benefits of Guided Inquiry re higher order thinking, student engagement, creativity, assessment for learning, differentiation and the National Curriculum are all too clear and they want more. The committee is made up of the principal, deputy principal, director of professional learning and the director of teaching and learning. We are pushed to the limit but it is highly satisfying and we feel so much more confident with it all now.

\section{Caddy's Creek Public School by Jenny Schefers}

This year I've trialled Guided Inquiry with students designing their own research questions. Up until this stage, we had been using Web Quests as the basis of our Guided Inquiry units.

I visited Christina Higgins, Santa Sabina Junior School, who very kindly shared her ideas and experiences. So last term I took the big plunge \& trialled a Year 4 Guided Inquiry unit (5 classes) based on the Early Australian Explorers. It was amazingly successful!! The students could construct their focus question \& supporting contributing questions very well. I used one class as a case study \& collated their Skinny Surveys. (This is an adaptation of SLIM Toolkit)

Although the students final presentations weren't very in-depth, their survey \& journal comments certainly reflected Kulthau's ISP roller coaster of emotions and a few very higher order quotes from some students! The research journey was amazing for all students.

We plan to do similar units in the future, that is, move beyond Web Quests \& have students design their own questions. 
Santa Sabina by Helen Schutz

This is what we are doing in a nutshell.

- Year 6 Major Interest project + one other project per term

- Year 7 history (roman Britain)

- Year 7 integrated project - one per term

- Year 8 history - one per semester (NZ and Modern world study)

- Year 8 PDHPE

- Year 9 PDHPE

- Year 10 English

- Year 11 SGP, HIP

- Year 12 Society and Culture

All of the above are not single classes but whole year groups! We are not analysing all the data although I have a stack on my desk from year 6 at the moment. I just don't have time to do it for all. Just concentrating on building up interest at this stage.

\section{St. Luke's Grammar School by Alicia Broadbent}

At St Luke's we have incorporated Guided Inquiry into two independent research tasks for Science and History. The History research task was choosing an event in Mod History, creating a question and researching - this was year with Year 9. The same group of students in Year 10 then used Guided Inquiry in a science research task. So that was interesting to see the students' progress.

The teachers have taken elements of GI and are now incorporating them into their assessment tasks.

\section{St Paul's Grammar School by Cathy Hill}

How does Guided Inquiry work with Gifted \& Talented students and IB Programme?

For a number of years I have been working with Yvonne Hammer (Director of Gifted Education \& Independent Learning) on an aspect of the IB Middle Years Programme - Approaches to Learning (ATL) - which looks at the following questions

- How do I learn best?

- How do I know?

- How do I communicate my understandings?

In looking at these questions ATL looks at students developing

- Organisational skills

- Information literacy

- Collaborative skills

- $\quad$ Problem solving

- Reflection.

In attempting to develop the school approach to Approaches to Leaning learning models were investigated using the resource Teaching Models in Education of the Gifted (2006) by Maker \& Schiever. Maker \& Schiever (2006, pp.4-11) when discussing the curricula for Gifted students suggests models of teaching/learning for Gifted students should allow for

Content modification through:

- Abstractness

- Complexity

- Variety

- Organisation

- Study of people

- Study of methods

Process modifications through:

(C) 2010 IASL, SLAQ and therein by the authors. Diversity Challenge Resilience: School Libraries in Action Proceedings of the $12^{\text {th }}$ Biennial School Library Association of Queensland, the $39^{\text {th }}$ International Association of School Librarianship Annual Conference incorporating the $14^{\text {th }}$ International Forum on Research in School Librarianship, Brisbane QLD Australia, 27 September - 1 October 2010. 
- $\quad$ Higher levels of thinking

- Open-endedness

- Discovery

- Evidence of Reasoning

- Freedom of Choice

- Group interaction

- Pacing \& variety

Product modification through:

- Real problems

- Real audiences

- Transformation

- Variety

- Self-select format

- Appropriate evaluation

- Learning environment modifications

- Learner centred

- Student independence

- Open environment

- Acceptance - understand student ideas; timing of value judgements; evaluation not judgement

- Complexity

- Varied groupings

- Flexibility

- Movement in \& out of the classroom environment.

While Maker \& Schiever (2006) provides many models it was felt that Kuhlthau's Information Search Process Model covered all the above providing a framework for intervention in the investigative process to support highly able students. The affective domain of this model is especially important and is a powerful tool in allowing students to move on.

The key to SPGS' experiences with Guided Inquiry (and not just with Gifted and Talented students) has been the framing and reframing of questions as the result of immersion in the literature of selected fields of inquiry along with students being able to determine the final product or form of communication.

Along with this the IB programme required integration of what it calls the Learner Profile through all units of work. The learner profile outlines the character of IB learners to be

- Inquirers

- Knowledgeable

- Thinkers

- Communicators

- Principled

- Open-minded

- Caring

- Risk-takers

- Balanced

- Reflective

I feel as do the other teachers who worked with Year $7 \& 8$ on the 2008 Guided Inquiry project that the students involved displayed all the above qualities - they just happen when working with GI they do not have to be forced.

\section{Bibliography}

IB learner profile booklet. (2006). International Baccalaureate Organization: Cardiff. Retrieved October 8, 2009, from http://www.ibo.org/programmes/documents/learner_profile_en.pdf

(C) 2010 IASL, SLAQ and therein by the authors. Diversity Challenge Resilience: School Libraries in Action Proceedings of the $12^{\text {th }}$ Biennial School Library Association of Queensland, the $39^{\text {th }}$ International Association of School Librarianship Annual Conference incorporating the $14^{\text {th }}$ International Forum on Research in School Librarianship, Brisbane QLD Australia, 27 September - 1 October 2010. 
Maker, CJ. \& Schiever, SW. (2005). Teaching models in education of the gifted $3^{\text {rd }}$ Edn. Austin, Texas. Pro-Ed.

\section{Conclusion}

Since the 2008 project, participating schools have benefited from Guided Inquiry both in acceptance of its inclusion into curriculum and of the findings from the project in terms of students' construction of knowledge and information behaviour. For teacher-librarians in these schools, inclusion of Guided Inquiry methods in the assignments of students has become commonplace, provided us with a means of ensuring that the information literacy skills of students are addressed in a systematic way as well as giving us opportunities for small scale action research any time the reflection sheets synonymous with Guided Inquiry are used. All of us have seen our workload increase exponentially, but it is exciting to report that after a long time of trying to introduce ideas of collaboration, CPPT, information literacy into schools that remain somewhat baffled, Guided Inquiry provides this opportunity. It is intricately woven into the fabric of assignments in schools, and as such cannot be seen as an add-on, or slightly peculiar 'librarían' thing.

Over the years, all teacher-librarians have developed the kinds of scaffolds now re-emerging and freshened up for use in Guided Inquiry units. They really are not new. What is new is the context in which we can place them. The context is the Information Search Process, which allows students to become aware of their own processes and allows teachers and teacher-librarians to frame the task, and to bring together in a meaningful way scaffolds which we might have used in an unconnected way in the past. New also, and central to the success of Guided Inquiry, is the feedback sought from students thoughout their process, which allows teachers and teacher-librarians to frame individual and group interventions, and which forms the basis for ongoing evidence-based practice. It is simple, it works, and is keeping us all busier than we've ever been before.

\section{References}

Centre for International Scholarship in School Libraries at Rutgers University (CISSL). (2005). Guided Inquiry. Retrieved August 12, 2010, from http://cissl.scils.rutgers.edu/guided_inquiry/introduction.html

Kuhlthau, C. C. (2004). Seeking meaning: A process approach to library and information services. 2nd edition, Westport CT: Libraries Unlimited.

Kuhltau, C.C. (2005). Model of the Information Search Process. Retrieved August 12, 2010, from http://comminfo.rutgers.edu/ kuhlthau/images/isp_chart.JPG

Kuhlthau, C. C., Maniotes, L. K. \& Caspari, A. K. (2007). Guided Inquiry: Learning in the 21st Century. Westport CT: Libraries Unlimited.

Kuhlthau, C. C, Heinstrom, J, \& Todd, R. J. (2008). The information search process revisited: is the model still useful? IR Information Research 13(4). Retrieved from http://nformationR.net/ir/13-4/paper355.html

Todd, Ross J. (2006). The leading of learning and evidence based practice. Scan 25(1), 26-27.

Todd, Ross J. (2009). Guided Inquiry: a framework for meaningful research in the school (DVD) Syba Signs, NSW, (54 min.)

Todd, Ross J.; Kuhlthau, Carol C. and Heinstrom, J.E. (2005). SLIM: A toolkit and handbook for tracking and assessing student learning outcomes of Guided Inquiry through the school library. Centre for International Scholarship in School Libraries at Rutgers University. Retrieved August 8, 2010, from http://cissl.rutgers.edu/SLIM_toolkit\%20Handbook.pdf

(C) 2010 IASL, SLAQ and therein by the authors. Diversity Challenge Resilience: School Libraries in Action Proceedings of the $12^{\text {th }}$ Biennial School Library Association of Queensland, the $39^{\text {th }}$ International Association of School Librarianship Annual Conference incorporating the $14^{\text {th }}$ International Forum on Research in School Librarianship, Brisbane QLD Australia, 27 September - 1 October 2010. 